\title{
UPAYA PENINGKATAN SIKAP PROFESIONAL GURU MELALUI PENINGKATAN KEBIASAAN MEMBACA
}

\author{
Biner Ambarita \\ FBS Universitas Negeri Medan (binerambarita@gmail.com; HP:08126561347)
}

\begin{abstract}
An Attempt to Improve Teachers' Professional Attitudes through Reading Habit Improvement. This study aims to investigate the effectiveness of the reading habit in increasing the professional attitude of history teachers in senior high schools (SHSs) in Medan City. This was a quasi-experimental study involving history teachers in SHSs in Medan City. The data were collected by using questionnaires, one to measure the level of teachers' reading habit and one to measure the level of teachers' professional attitude. The data were analyzed using the analysis of covariance. The results of this study showed that the average level of teachers' reading habit increased, followed by the increase of the level of teachers' professional attitude. It can be concluded that teachers' condition after the treatment is better. In other words, the reading habit is effective to increase the professional attitude of history teachers in SHSs in Medan City.
\end{abstract}

Keywords: reading habit, professional attitude

\section{PENDAHULUAN}

Pendidikan bertujuan untuk meningkatkan kualitas sumber daya manusia dalam berbagai dimensi. Dalam UU No. 20 Tahun 2003 tentang Sistem Pendidikan Nasional disebutkan bahwa "Pendidikan nasional berfungsi mengembangkan kemampuan dan membentuk watak serta peradaban bangsa yang bermartabat dalam rangka mencerdaskan kehidupan bangsa, bertujuan untuk berkembangnya potensi peserta didik agar menjadi manusia yang beriman dan bertakwa kepada Tuhan Yang Maha Esa, berakhlak mulia, sehat, berilmu, cakap, kreatif, mandiri, dan menjadi warga negara yang demokratis serta bertanggung jawab."

Pendidikan bukan hanya sekedar penguasaan materi dari setiap mata pelajaran, namun lebih dari itu, diharapkan pendidikan dapat menghasilkan orang yang mampu mengaktualisasikan seluruh potensinya secara optimal. Dengan potensi yang telah diaktualkan itu, seseorang dapat mendayagunakan serta menggali seluruh potensi alam dan lingkungannya secara produktif dan kompetitif sehingga ia mampu memenuhi kebutuhannya serta bersaing dan menjawab tantangan yang dihadapi dalam masyarakat dinamis tersebut. Semua ini dapat diperoleh lewat pendidikan yang berkualitas.

Salah satu masalah dalam pendidikan nasional yang masih tetap hangat dibicarakan adalah masalah kualitas hasil pendidikan. Berdasarkan skor ratarata peserta ujian masuk perguruan tinggi negeri (UMPTN) diketahui bahwa 
raw input perguruan tinggi dari tahun ke tahun menurun. Sementara itu, berdasarkan hasil laporan Badan Perserikatan Bangsa-Bangsa (PBB) untuk bidang pendidikan, United Nation Educational Scientific and Cultural Organization (UNESCO, 2007), menunjukkan peringkat Indonesia dalam hal pendidikan turun dari peringkat 58 menjadi peringkat 62 di antara 130 negara di dunia. Education Development Index (EDI) Indonesia adalah 0.935, di bawah Malaysia (0.945) dan Brunei Darussalam (0.965). Menurut Chapman (1998) bahwa permasalahan pendidikan Indonesia adalah rendahnya kualifikasi umum (low general qualifications) sebagian guru, rendahnya penguasaan guru terhadap materi pembelajaran, dan rendahnya status guru.

Kinerja pendidikan di Indonesia masih harus ditingkatkan higga terlepas dari keprihatinan. Hal ini merupakan tantangan bagi pemerintah, pendidik, dan masyarakat Indonesia untuk melakukan penanggulangan secepatnya. Untuk itu, perlu usaha ke arah peningkatan kualitas pendidikan secara menyeluruh.

Mempertimbangkan bahwa perkembangan ilmu pengetahuan dan teknologi serta mobilitas masyarakat yang serba cepat, maka pendidikan juga seyogianya harus tanggap dengan kondisi yang dinamis ini. Pendidikan harus menyiapkan peserta didik agar mampu menghadapi segala perubahan yang mungkin terjadi. Salah satu komponen dalam pendidikan yang harus tanggap dengan kondisi ini adalah guru. Untuk itu, guru-guru perlu didorong untuk terus-menerus mengembangkan wa- wasan dan kompetensinya sesuai dengan perkembangan yang ada. Selain itu, guru juga perlu meningkatkan kompetensinya sehingga mampu membina anak didik menguasai sejumlah kompetensi yang diperlukan sehingga mampu mengantisipasi perubahan dan perkembangan yang akan muncul. Guru merupakan faktor dominan dalam upaya pembenahan kualitas pendidikan, mengingat peranan guru itu sangat strategis dalam proses pembelajaran yang bermutu. Pembelajaran yang bermutu menuntut proses pendidikan harus berjalan dengan baik. Hal ini dapat tercapai apabila ditangani secara profesional (Tilaar, 2000).

Profesionalisme guru merupakan hal yang diperdebatkan akhir-akhir ini. Peningkatan profesionalisme guru dipandang sebagai salah satu upaya yang dapat meningkatkan kualitas pendidikan. Salah satu variabel karakteristik guru yang sangat berhubungan dengan profesinya adalah sikap guru terhadap profesi itu sendiri. Dalam banyak studi mengenai sikap, Hasan (1990) mengatakan bahwa sikap memiliki pengaruh terhadap unjuk kerja seseorang. Apabila diinginkan terjadi peningkatan kinerja guru, sikap profesionalismenya juga perlu ditingkatkan. Peningkatan profesionalisme dalam pendidikan dan pengajaran dalam hal ini para guru, banyak ditentukan oleh sikap para guru tersebut terhadap profesi guru itu sendiri. Tanpa sikap yang positif terhadap profesi yang digelutinya, mustahil mereka mau bertindak secara profesional. Persoalan sikap ini sangat menentukan karena sikap berhubungan secara positif dengan kinerja dan pada akhirnya 
sangat berpengaruh pada hasil pendidikan itu sendiri. Itulah sebabnya, masalah sikap guru terhadap profesinya perlu mendapat pengkajian sebagai fokus permasalahan.

Wawasan guru merupakan faktor yang mempengaruhi kemampuan guru menjalankan profesinya semaksimal mungkin. Semakin luas wawasan guru mengenai bidang keahliannya, akan semakin baik ia menjalankan profesinya. Oleh karena itu, setiap guru dituntut untuk melakukan persiapan yang matang setiap kali melakukan pembelajaran dan hal ini dilakukannya. Persiapan ini akan semakin matang jika guru menguasai berbagai informasi aktual yang terkait dengan bidang ilmunya. Dengan penguasaan informasi aktual tersebut, guru akan dapat menawarkan pembelajaran yang relevan dengan kondisi aktual yang tentunya akan lebih menarik bagi peserta didik. Penguasaan informasi secara formal dan informal hanya dapat dilakukan secara efektif melalui kegiatan membaca, baik melalui jurnal-jurnal, buku-buku referensi, maupun media massa baik cetak maupun elektronik. Oleh karena itu, kebiasaan membaca merupakan salah satu cara untuk meningkatkan wawasan guru mengenai segala hal yang terkait dengan profesinya.

Peningkatan sikap profesionalisme guru merupakan harapan dari setiap unsur pendidikan. Seorang guru yang profesional harus memiliki kebiasaan membaca yang baik. Sebab perkembangan ilmu yang sangat pesat membawa perubahan yang cepat pula dalam kehidupan manusia. Agar pengajarannya tetap relevan dengan perkembang- an tersebut, guru harus selalu berusaha menggali informasi terkait dengan perkembangan tersebut. Kebiasaan membaca yang baik dari seorang guru akan berakibat terhadap makin luas dan dalam akumulasi informasi dalam dirinya berupa pengetahuan-pengetahuan yang berkaitan dengan profesinya sebagai guru. Keluasan dan kedalaman akumulasi informasi seperti ini tentu saja akan mendukung terhadap peningkatan kualitas pembelajaran yang ditawarkan. Hal ini tentu saja merupakan indikator bagi peningkatan profesionalitas guru itu sendiri. Kesadaran guru untuk senantiasa mengaktualkan informasi yang dibutuhkan terkait dengan profesinya sebagai guru menunjukkan sikap yang positif terhadap profesi itu sendiri. Berdasarkan uraian sebelumnya yang menunjukkan hubungan antara kebiasaan membaca dengan sikap profesionalisme guru, muncul pertanyaan apakah peningkatan kebiasaan membaca guru efektif untuk meningkatkan sikap profesionalisme guru? Untuk menjawab pertanyaan ini dilakukan penelitian yang bertujuan untuk memeriksa keefektifan dari peningkatan kebiasaan membaca guru dalam upaya meningkatkan sikap profesionalisme guru.

Day (2002) melihat perkembangan dan perubahan identitas dan profesionalisasi guru dan menyatakan bahwa guru mengalami masalah dalam mempertahankan motivasi, komitment mengembangkan profesionalisme melalui pengembangan berbagai pengetahuan yang mendalam, kepuasan kerja, keefektifan kerja. Dalam pengembangan profesionalisme guru harus terus-menerus memperbaharui ilmu dan penge- 
tahuannya dari berbagai sumber informasi, seperti buku, e-book, penelitian dan lain sebagainya.

\section{METODE}

Sesuai dengan tujuan penelitian ini metode yang digunakan adalah metode eksperimen. Dengan kata lain dalam penelitian ini akan diuji efek dari suatu perlakuan terhadap kelompok sampel tertentu. Perlakuan yang dimaksud adalah pengkondisian sehingga kebiasaan membaca guru meningkat. Kebiasaan membaca dalam penelitian ini diartikan sebagai aktivitas penambahan pengetahuan melalui kegiatan membaca yang diukur dalam jam/waktu yang digunakan setiap hari untuk membaca buku, internet, koran dan majalah yang berhubungan dengan profesinya, serta yang secara tidak langsung berpengaruh terhadap pekerjaannya sebagai guru. Sikap profesional dapat diartikan sebagai respon seseorang dalam bentuk setuju atau tidak setuju terhadap dimensi-dimensi profesi yang digelutinya. Dimensi-dimensi profesi guru dalam penelitian ini adalah dimensi persiapan mengajar, pelaksanaan pembelajaran, dan evaluasi pembelajaran.

Pengkondisian diwujudkan dalam bentuk kompetisi karya tulis dan pengawasan terhadap bahan ajar yang disiapkan guru. Penelitian ini dilakukan di seluruh SMU Negeri Medan sebanyak 18 sekolah. Sampel penelitian dipilih dengan teknik random sederhana sebanyak 40 orang guru Sejarah dari 7 sekolah. Dalam penelitian ini, terdapat dua variabel yaitu kebiasaan membaca dan sikap profesional guru. Kebiasaan membaca diukur dengan angket terbuka, sementara sikap profesional diukur dengan angket tertutup. Sebelum instrumen digunakan telah diuji kualitasnya meliputi validitas konstruk dan validitas isi serta reliabilitasnya. Hasil penilaian ahli dan ujicoba lapangan menunjukkan bahwa instrumen yang digunakan valid dan reliabel. Selanjutnya untuk menganalisis data kebiasaan membaca dan data sikap profesionalisme guru sebelum dan sesudah perlakuan digunakan statistik inferensial Anakova. Data yang akan dianalisis adalah kebiasaan membaca guru sebagai variabel penyerta atau kovariat dan sikap profesionalisme guru sebagai variabel terikat. Dalam hal ini, kondisi awal guru, terkait dengan variabel penelitian, yaitu kebiasaan membaca dan sikap profesionalismenya, tidak dapat diabaikan begitu saja. Mengingat bahwa kondisi awal masingmasing guru tidak sama dan sulit untuk dikontrol, namun tetap memberi kontribusi pada perkembangan akibat perlakuan yang dirancang. Statistik inferensial Anakova dipilih dalam penelitian ini karena dalam penelitian ini terdapat variabel kovariat sebagai variabel bebas yang sulit untuk dikontrol tetapi dapat diukur bersamaan dengan variabel terikat.

\section{HASIL PENELITIAN}

Setelah instrumen penelitian disebarkan pada kelompok sampel, diperoleh data tentang kebiasaan membaca dan sikap profesionalisme guru, yang dibutuhkan untuk proses analisis selanjutnya. Deskripsi data hasil penelitian disajikan pada Tabel 1 berikut. 
Tabel 1: Ringkasan Deskripsi Data Penelitian

\begin{tabular}{lcccc}
\hline & \multicolumn{2}{c}{ Sebelum Perlakuan } & \multicolumn{2}{c}{ Setelah Perlakuan } \\
\cline { 2 - 5 } & $\begin{array}{l}\text { Kebiasaan } \\
\text { Membaca }\end{array}$ & Sikap Profesional & $\begin{array}{l}\text { Kebiasaan } \\
\text { Membaca }\end{array}$ & Sikap Profesional \\
\hline Nilai Min & 105 & 45 & 146 & 62 \\
Nilai Max & 510 & 107 & 716 & 110 \\
Rata-rata & 278.725 & 65.725 & 339.75 & 81 \\
Simp. Baku & 121.804 & 11.05693 & 127.450694 & 11.05759 \\
Jumlah & 11149 & 2629 & 13590 & 3284 \\
\hline
\end{tabular}

Berdasarkan ringkasan data pada Tabel 1, dapat dilihat perbandingan antara kondisi guru sebelum dan sesudah perlakuan terkait dengan variabel penelitian, yaitu kebiasaan membaca de- ngan sikap profesionalisme guru. Perbandingan data kebiasaan membaca sebelum dan setelah perlakuan dapat dilihat pada diagram berikut.

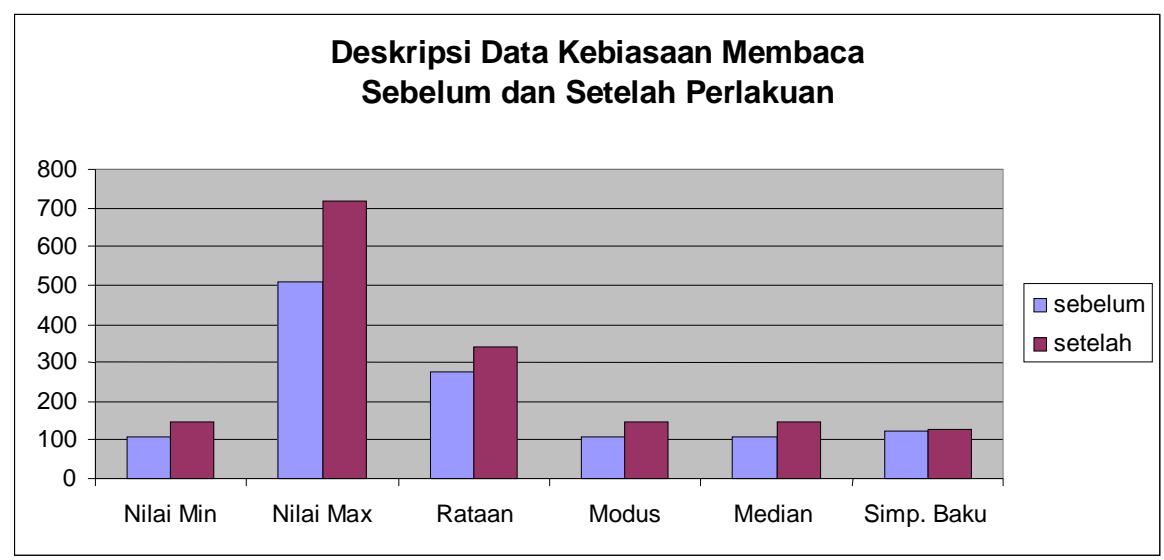

Gambar 1 Data Kebiasaan Membaca Sebelum dan Setelah Perlakuan

Pada diagram ini dapat dilihat peningkatan skor kebiasaan membaca guru, terutama pada nilai maksimum terlihat selisih yang cukup signifikan hingga 206 point. Dapat dilihat juga bahwa rerata kebiasaan membaca setelah perlakuan lebih tinggi daripada sebelumnya, demikian juga halnya dengan modus dan median. Dengan mempertimbangkan bahwa simpangan baku sebelum dan sesudah perlakuan tidak jauh berbeda, maka berdasarkan analisis sementara terhadap diagram ini dapat dikatakan bahwa rerata skor kebiasaan membaca setelah perlakuan cenderung lebih tinggi dari rerata skor kebiasaan membaca sebelum perlakuan.

Sementara itu perbandingan data kebiasaan membaca sebelum dan setelah perlakuan dapat dilihat pada diagram berikut. 


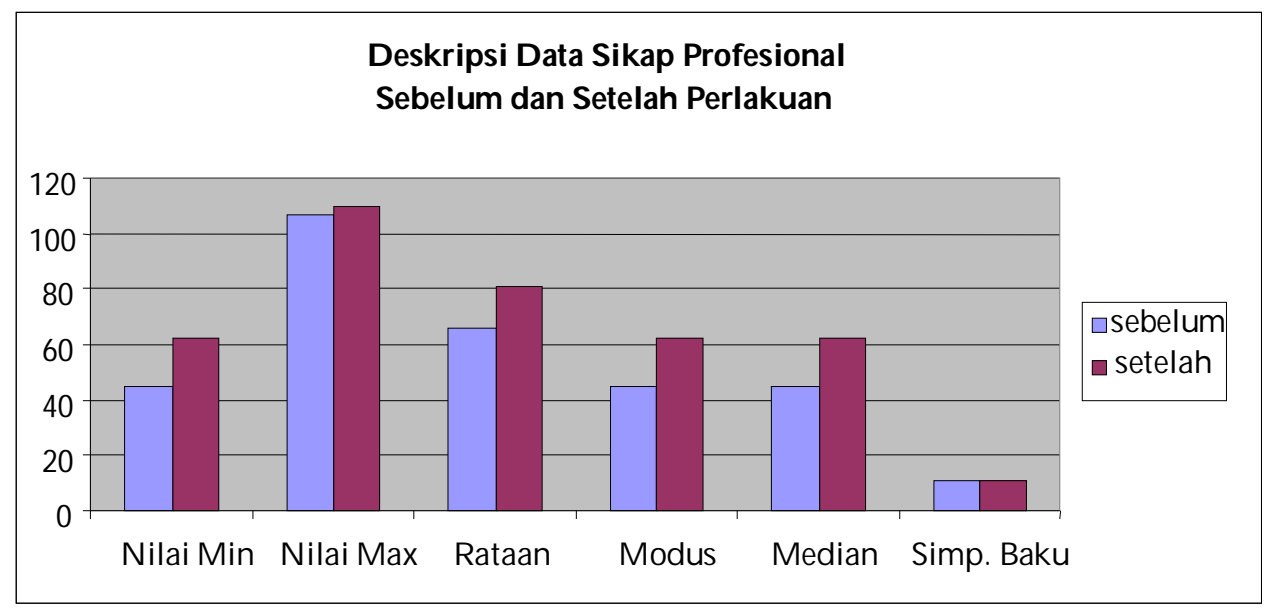

Gambar 2 Data Sikap Profesional Sebelum dan Setelah Perlakuan

Pada diagram ini, dapat dilihat peningkatan skor nilai minimum dan maksimum sikap profesional guru sebelum dan sesudah perlakuan yang masing-masing selisihnya 17 dan 3 point. Selisih terbesar dilihat pada nilai maksimum, namun ternyata jika ditinjau dari selisih rerata skor sikap profesional, ternyata rerata setelah perlakuan lebih tinggi daripada sebelumnya, demikian juga halnya dengan modus dan median. Hal ini menunjukkan bahwa skor sikap profesional setelah perlakuan cenderung lebih tinggi. Hal ini diperkuat lagi dengan mempertimbangkan bahwa simpangan baku sebelum dan sesudah perlakuan tidak jauh berbeda. Dengan demikian, berdasarkan analisis sementara terhadap diagram ini dapat dikatakan bahwa rerata skor sikap profesional setelah perlakuan cenderung lebih tinggi dari rerata skor sikap profesional sebelum perlakuan.

Selanjutnya, untuk penarikan kesimpulan yang lebih dapat dipertanggungjawabkan, digunakan analisis sta- tistik inferensial Anakova untuk menjawab pertanyaan penelitian, yaitu: apakah upaya meningkatkan kebiasaan membaca guru efektif untuk meningkatkan sikap profesional guru.

Berdasarkan hasil perhitungan, diperoleh model regresi setelah perlakuan adalah sebagai berikut: $\mathrm{Y}_{\mathrm{E}}=68,858+$ $0,039 \chi_{\text {E. }}$ Model regresi sebelum perlakuan adalah sebagai berikut: $Y_{K}=44,71+$ $0,075 X_{K}$

Selanjutnya, dilakukan uji statistik yang sesuai, yaitu: uji linieritas, uji independensi, uji kesamaan dan uji kesejajaran, dengan menggunakan taraf signifikansi 5\%. Dari hasil uji independensi diperoleh kebiasaan membaca $(X)$ mempunyai pengaruh yang signifikan terhadap sikap profesionalisme guru (Y) untuk model regresi baik sebelum maupun setelah perlakuan. Untuk data setelah perlakuan dperoleh $F_{h i t}=8,147$ dan $\mathrm{F}_{0,05 ; 1,38}=4,098$. Sedangkan untuk data sebelum perlakuan diperoleh Fhit $=$ 84.518 dan $\mathrm{F}_{0,05 ; 1,38}=4,098$.

Berdasarkan hasil uji linieritas di- 
simpulkan bahwa model regresi linier yang diperoleh dapat digunakan untuk menunjukkan pengaruh kebiasaan membaca terhadap terhadap sikap profesionalisme guru, baik sebelum maupun setelah perlakuan. Untuk data setelah perlakuan dperoleh $\mathrm{F}_{\text {hit }}=0,803$ dan $\mathrm{F}_{0,05 ; 22,16}$ $=2,254$. Sedangkan untuk data sebelum perlakuan diperoleh $\mathrm{F}_{\mathrm{hit}}=0,259$ dan $\mathrm{F}_{0,05}$; $22,16=2,254$.

Pada uji kesamaan dua model regresi diperoleh regresi linier data ga- bungan $\hat{Y}=55,69+0,07 X$. Dengan taraf signifikan $\alpha=5 \%$, diperoleh $\mathrm{F}_{0.05 ;}, 2,76=$ 3,12. Ternyata $F_{h i t}=22.63>F_{0.05 ;} ; 2,76$, maka disimpulkan model regresi linier baik sebelum maupun setelah perlakuan tidak sama atau tidak berimpit.

Selanjutnya, berdasarkan uji kesejajaran model regresi, diperoleh Fhit $=$ 3,45 dan $\mathrm{F}_{0,05 ;}, 76=3,967$. Dengan demikian, $F_{h i t}<F_{0,05} ; 1,76$, maka disimpulkan bahwa model regresi linier baik sebelum maupun setelah perlakuan sejajar.

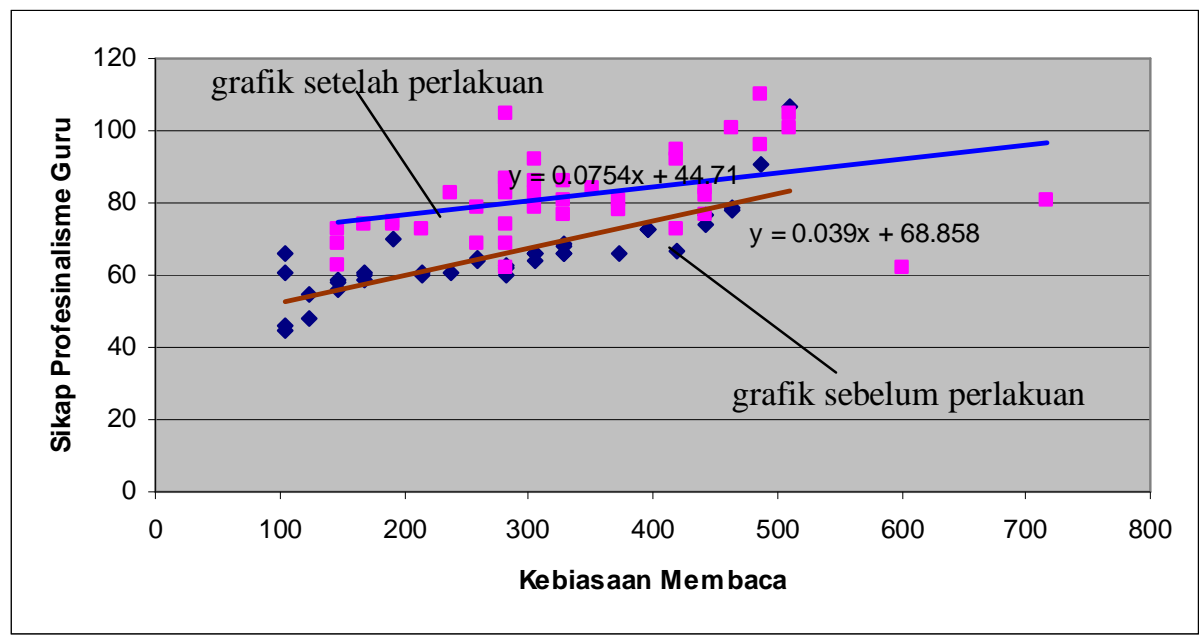

Gambar 3 Grafik Anakova sebelum dan setelah Perlakuan

Berdasarkan hasil uji kesamaan dan uji kesejajaran, diketahui bahwa kedua model regresi tidak sama, tetapi sejajar. Dengan demikian, dapat disimpulkan bahwa ada perbedaan antara sikap profesionalisme guru sebelum dan setelah perlakuan.

Karena konstanta garis regresi untuk data setelah perlakuan lebih besar dari konstanta garis regresi untuk data sebelum perlakuan, secara geometris, garis regresi untuk data setelah perlakuan di atas garis regresi untuk data sebelum perlakuan. Ini berarti bahwa sikap profesionalisme guru setelah perlakuan lebih baik dari sikap profesionalisme guru sebelum perlakuan.

\section{PEMBAHASAN}

Berdasarkan hasil penelitian ini diketahui bahwa kompetisi karya tulis dan pengawasan terhadap bahan ajar yang disiapkan guru berpengaruh positip terhadap kebiasaan membaca. Kebiasaan membaca akan membangun budaya membaca. 
Budaya membaca dapat membantu meningkatkan pola berpikir yang lebih kritis dan analitis. Kebiasaan membaca yang tinggi akan menambah pengetahuan pembaca. Resnick (1986) menyebutkan bahwa banyaknya pengetahuan yang dimiliki oleh seseorang ditentukan oleh banyaknya informasi yang didapatkan melalui kegiatan membaca dan biasanya orang-orang yang profesional dalam pekerjaannya kebanyakan melakukan hal seperti itu. Lebih lanjut dikatakan bahwa keanggotaan seseorang dalam suatu profesi dikenali dengan pengetahuan dan kemampuan khusus profesi yang dimilikinya. Dengan demikian, guru yang profesional seharusnya membina kebiasaan membaca ini untuk menunjang keprofesionalannya. Kebiasaan membaca yang tinggi juga menunjukkan sikap profesional yang tinggi.

Seorang profesional akan selalu berusaha mengembangkan wawasan dan pengetahuan yang terkait profesinya. Setiap perkembangan seseorang dalam pengetahuan dan kemampuan ini menunjukkan kemajuan seseorang dalam bidang profesinya. Metzger (1997) menyebutkan bahwa menjadi profesional berarti menunjukkan adanya kemajuan. Dengan demikian, seseorang guru haruslah mengembangkan pengetahuan dan kemampuannya dalam profesinya sebagai guru.

Salah satu upaya mengembangkan pengetahuan dan kemampuan adalah melalui kebiasaan membaca. Tampubolon (1987:228) mengatakan bahwa kebiasaan adalah kegiatan yang mendarah daging pada diri seseorang, sedangkan membaca adalah kegiatan fisik dan mental yang dapat berkembang menjadi suatu kebiasaan. Lebih lanjut dikatakan bahwa dalam usaha pembentukan kebiasaan membaca, tiga aspek yang perlu diperhatikan adalah minat, motivasi, dan keterampilan membaca. Hal ini berarti untuk dapat meningkatkan kebiasaan membaca guru perlu dipertimbangkan apa yang menjadi minat guru. Dalam hal ini, dapat diasumsikan bahwa bidang keahlian guru adalah sesuatu yang diminati oleh guru. Dengan kata lain, bacaan yang terkait dengan bidang keahliannya merupakan sesuatu yang diminati oleh guru.

Motivasi merupakan salah satu unsur penting dalam meningkatkan kebiasaan membaca. Untuk itu, perlu pengkondisian yang dapat membangkitkan motivasi guru untuk membaca. Terdapat dua jenis motivasi yaitu motivasi ekstrinsik dan motivasi intrinsik. Dengan demikian, kondisi yang dirancang hendaknya menyentuh motivasi ekstrinsik dan intrinsik guru. Sesungguhnya motivasi ekstrinsik sendiri dapat dipandang sebagai pemicu bagi motivasi intrinsik. Sebab, kontribusi dari pengaruh atau unsur positif dari luar pribadi seorang individu pada akhirnya akan membangkitkan motivasi dalam diri individu tersebut untuk mencapai unsur positif yang menjadi tawaran dari motivasi ekstrinsik sebelumnya. Dengan merancang kondisi yang dapat menyentuh kedua jenis motivasi ini diharapkan dapat meningkatkan kebiasaan membaca guru. Dalam hal ini pengkondisian yang dimaksud diwujudkan dalam bentuk kompetisi karya tulis dan pengawasan terhadap bahan ajar yang disiapkan guru. 
Kompetisi karya tulis dipilih sebab hadiah yang ditawarkan dapat dipandang sebagai motivasi ekstrinsik. Guru yang mengikuti kegiatan ini secara tidak langsung diwajibkan untuk membaca. Sebab, karya ilmiah yang akan ditulis menuntut kajian literatur yang relevan. Semakin banyak sumber literatur yang dibaca, akan semakin baik karya tulis yang dihasilkan guru. Sebagaimana diuraikan sebelumnya, hadiah yang menjadi motif eksternal akan dapat membangun rasa ingin dalam diri guru untuk berhasil mencapai hadiah yang ditawarkan. Rasa ingin ini sendiri dapat dipandang sebagai motif yang muncul dalam diri guru.

Sementara itu, kegiatan pengawasan bahan ajar menekankan pada integrasi informasi dan perkembangan aktual dalam pembelajaran. Kegiatan ini dipilih sebab secara tak langsung mendorong guru untuk selalu mencari informasi perkembangan terkini yang relevan dengan materi ajarnya. Alternatif untuk kewajiban ini adalah dengan membaca. Kegiatan ini juga dapat membangun motivasi intrinsik dalam diri guru. Dalam hal ini setiap guru butuh hasil penilaian yang baik. Kebutuhan ini akan mendorong guru dari dalam dirinya untuk meningkatkan kualitas kinerjanya. Guru akan menempuh berbagai upaya untuk meningkatkan wawasan dan kompetensinya termasuk membaca. Pada akhirnya, pengawasan ini memungkinkan berkembangnya kesadaran guru akan perlunya pengaktualan wawasan mereka akan segala informasi yang terkait dengan bidang ilmunya. Peralihan kondisi guru dari diwajibkan untuk mengaktualkan wa- wasannya menjadi merasa perlu untuk mengaktualkan wawasannya, merupakan harapan dari kegiatan pengawasan ini. Pengawasan ini lebih menekankan pada pembinaan guru serta bantuan dalam pengembangan situasi pembelajaran yang lebih baik. Dengan demikian, kegiatan pengawasan ini sejalan dengan upaya memperbaiki dan meningkatkan kemampuan profesional guru.

Bagi guru-guru ilmu sosial membaca menduduki tempat sangat penting terutama disebabkan oleh karakteristik ilmu sosial itu sendiri. Perkembangan ilmu yang sangat pesat membawa perubahan yang cepat pula dalam kehidupan umat manusia. Untuk itu, guru umumnya, khususnya guru sosial wajib tanggap terhadap kemajuan dan perubahan yang ada. Kemajuan-kemajuan ini memberi dampak yang sangat luas dalam pengembangan materi pengajaran ilmu sosial, suatu aspek pengetahuan profesional yang harus dikuasai guru-guru ilmu sosial. Oleh karena itu, membaca merupakan tantangan profesi bagi guru ilmu sosial.

Berkaitan dengan itu, Maister (1993) mengemukakan bahwa seorang profesional, baik dalam bisnis maupun edukasi, minimal harus membaca 300.000 kata dalam seminggu. Lebih lanjut, dikatakan bahwa para profesional dapat membaca minimal 250 kata per menit. Hal ini berarti seorang profesional minimal menghabiskan waktu selama 20 jam per minggu. Kalau satu minggu dihitung enam hari kerja, seorang profesional minimal menghabiskan waktu selama 140 menit per hari ( $2 \frac{1}{3}$ jam). 
Terkait dengan pengembangan pengetahuan dan profesionalisme, Crook (2005) mengemukakan bahwa kemampuan membaca dan menulis (literacy) guru dan siswa terkait dengan perubahan media buku menjadi buku elektronik (e-book) serta akses terhadapnya dengan menggunakan ICT.

Profesionalisme menjadi tuntutan setiap pekerjaan. Apalagi profesi guru yang sehari-hari menangani makhluk hidup, yaitu siswa yang memiliki berbagai karakteristik yang masing-masing tidak sama. Pekerjaan sebagai guru menjadi lebih berat tatkala menyangkut peningkatan kemampuan anak didiknya, sedangkan kemampuan dirinya mengalami stagnasi. Dengan demikian, seorang guru harus tetap berusaha mengembangkan dan mengaktualkan dirinya sehingga mampu membimbing anak didiknya untuk mengembangkan diri mereka.

Hasan (1990) mengatakan bahwa sikap profesional merupakan bagian dari profesionalisme. Profesionalisme itu sendiri atas pengetahuan dan pemahaman mengenai sikap terhadap profesi dan unjuk kerja profesi. Menurut Hasan (1990:13) ketiganya diperoleh melalui pendidikan yang khusus mengenai profesi tersebut. Tetapi, aspekaspek tersebut harus dikembangkan lebih lanjut setelah seseorang berada dalam profesi tersebut. Profesi di sini diartikan sebagai suatu bidang pekerjaan di mana seseorang mengabdikan dirinya. Berdasarkan kutipan ini profesi bukan sekadar penguasaan kompetensi yang terkait dengan bidang ilmu yang diperoleh melalui pendidikan khusus, tetapi juga terkait dengan bagaimana sikap individu profesional terhadap profesi yang digelutinya.

Show dan Wrigh (1997:2) mendefinisikan sikap sebagai: "A relative enduring system of evaluative, affective reactions based upon and reflecting the evaluative or beliefs which have been learned about the characteristics of social object or class objects." Menurut mereka, sikap mengacu pada sistem evaluasi dan aspek reaksi afektif yang didasarkan pada refleksi keyakinan mengenai karakteristik sosial. Berdasarkan pendapat ini sikap seseorang dipengaruhi oleh sistem afektif yang diyakini oleh seseorang. Dengan konsep sikap seperti ini, ada komponen afektif yang menjadi dasar bagi setiap respon seseorang. Dengan demikian, operasional pengukuran sikap dapat diwujudkan dalam bentuk skala sikap. Skala sikap tersusun dari pertanyaan atau pernyataan-pernyataan yang bervariasi tingkat kepositifan atau kenegatifan mengenai suatu objek. Respon terhadap pernyataan tersebut kemudian dipergunakan untuk meramalkan adanya evaluasi. Pernyataan dalam skala sikap menunjukkan bahwa karakteristik objektif yang dapat direspons adalah positif atau negatif atau bahkan netral. Jadi, skala akan mengukur derajat kepositifan atau kenegatifan dari reaksi afektif. Dengan demikian, hubungan antara konsepsi teoretis tentang sikap dan konsekuensi pengukurannya menjadi jelas.

Fishben dan Ajzen (1990) menegaskan bahwa sikap mempunyai dua ciri, yaitu arah sikap dan derajat perasaan. Arah sikap di sini diartikan sebagai reaksi positif atau negatif dari seseorang terhadap suatu objek. Reaksi po- 
sitif atau negatif dari seseorang terhadap suatu objek. Reaksi positif dapat diartikan sebagai semacam pendekatan diri terhadap suatu objek, dan sebaliknya reaksi negatif menunjukkan pada pengindraan dari suatu objek. Selanjutnya, derajat perasaan dinyatakan sebagai salah satu ciri dari sikap karena memiliki dimensi evaluasi atau penilaian terhadap suatu objek. Dengan derajat perasaan ini, orang tidak hanya menilai suatu objek secara dikotomi, seperti senang atau tidak senang, setuju atau tidak setuju, baik, dan buruk, menguntungkan atau tidak menguntungkan, tetapi juga dapat memiliki gradasi yang lebih luas, seperti sangat senang, senang, cukup senang, tidak senang, dan sangat tidak senang, dan yang sejenisnya, sehingga membantu dalam menetapkan perasaan tersebut.

Sikap positif seorang guru terhadap profesinya akan mendorong kinerja (performance) yang lebih baik. Gredler (1991:193) yang mengutip pendapat Gagne mengungkapkan bahwa sikap adalah kapabilitas yang mempengaruhi pilihan tentang tindakan yang akan diambil. Dengan demikian, sikap dapat diamati dari tindakan-tindakan tersebut. Jadi, dapat dikatakan bahwa sikap tidak dapat diamati secara langsung tetapi akan terlihat melalui indikator-indikator. Anglin (1995) mengutip pendapat Guttman yang menyatakan bahwa sikap sebagai totalitas perilaku yang mengacukepada sesuatu. Dengan mengamati perilaku yang dimaksud, kita dapat mengidentifikasi sikap seseorang.

Sikap positif seorang guru terhadap profesinya akan dinyatakan dalam bentuk rasa senang terhadap pekerjaan yang dituntut oleh profesi tersebut. Karena itu, di samping pengetahuan dan unjuk kerja, sikap profesional turut menentukan keberhasilan seseorang dalam profesi yang digelutinya. Upaya peningkatan sikap profesional guru melalui peningkatan kebiasaan membaca adalah efektif sesuai dengan hasil penelitian ini

\section{PENUTUP}

Berdasarkan hasil penelitian, diperoleh simpulan bahwa sikap profesionalisme guru setelah kebiasaan membacanya ditingkatkan lebih baik dari sikap profesionalisme guru sebelumnya. Dengan kata lain, peningkatan kebiasaan membaca guru merupakan upaya yang efektif dalam meningkatkan sikap profesionalisme guru. Dengan demikian, dapat disarankan bahwa untuk meningkatkan sikap profesionalisme guru dapat dilakukan melalui upaya peningkatan kebiasaan guru membaca. Dalam hal ini, ditekankan bahwa upaya peningkatan kebiasaan guru membaca dilakukan melalui pemberian kondisi yang dapat membangkitkan motivasi guru untuk membaca, terutama motivasi internal.

\section{UCAPAN TERIMA KASIH}

Dengan ini penulis mengucapkan terima kasih kepada seluruh Kepala Sekolah SMA Negeri Medan, dan seluruh guru sejarah SMA Negeri Medan, serta pihak-pihak yang terlibat dalam penelitian ini yang tidak mungkin disebutkan satuper satu. Kerjasama yang baik serta sumbangan tenaga dan pemikiran selama penelitian ini dilaksanakan sangat menentukan keberhasilan 
penelitian ini. Semoga kesempatan itu memberi dampak positif bagi kita semua.

\section{DAFTAR PUSTAKA}

Anglin, J.G. 1995. Instructional Techno$\log y$, Past and Future. Englewood: Libraries Unlimited, Inc.

Chapman David W., Don Adams. "The Quality of Education in Asia: The Parennial Priority". International Journal of Educational Research 29 (1998) 643-665.

Crook, Charles. "Addressing Research at the Intersection of Academic Literacies and New Technology". International Journal of Educational Research 43 (2005) 509-518.

Day, Christopper. "School Reform and Transitions in Teacher Professionalism and Identity". International Journal of Education Research 37 (2002) 677-692.

Fishben, M. dan Ajzen, Icek 1990. Belief, Attitude, Intention and Behavior. New York: McGraw Hill.

Gredler, B.E.M. 1991. Belajar dan Membelajarakan. Jakarta: Rajawali.
Hasan, S.H. 1990. “Guru Pemimpin dan Profesionalisme". Makalah disajikan pada LDKM HIMA Sejarah.

Maister, D.H. 1993. Managing the Professional Service Firm. New York: The Free Press.

Metzger, W.P. 1997. A Spectre Haunts American Scholars: The Spectre of Professionalism, Educational Researcher, 16, 6 .

Resnick, L.B. 1986. A Prisidential Address, Educational Researcher, 19, 7.

Show, M.E. dan Wrigh, J.M. 1997. Scale for Measurement of Attitude. London: McGraw Hill.

Tampubolon, D.P. (1987). Kemampuan Membaca dan Teknik membaca (Membaca Efektif dan Efisien). Bandung: Angkasa.

Tilaar, H.A.R. 2000. Paradigma Baru Pendidikan Nasional. Jakarta: Rineka Cipta.

UNESCO. 2007. Peringkat Pendidikan 130 Negara di Dunia. Badan Perserikatan Bangsa-Bangsa (PBB). 